\title{
Migrainous Infarction
}

National Cancer Institute

\section{Source}

National Cancer Institute. Migrainous Infarction. NCI Thesaurus. Code C117024.

Migraine associated with an ischemic brain lesion. 